\title{
Simulating Future Runoff in a Complex Terrain Alpine Catchment with EURO-CORDEX Data
}

\author{
GERHARD SMIATEK \\ Institute of Meteorology and Climate Research, Karlsruhe Institute of Technology, Garmisch-Partenkirchen, Germany \\ HARALD KUNSTMANN \\ Institute of Meteorology and Climate Research, Karlsruhe Institute of Technology, Garmisch-Partenkirchen, \\ and Institute of Geography, University of Augsburg, Augsburg, Germany
}

(Manuscript received 12 October 2018, in final form 3 July 2019)

\begin{abstract}
With large elevation gradients and high hydrometeorological variability, Alpine catchments pose special challenges to hydrological climate change impact assessment. Data from seven regional climate models run within the Coordinated Regional Climate Downscaling Experiments (CORDEX), each driven with a different boundary forcing, are used to exemplarily evaluate the reproduction of observed flow duration curves and access the future discharge of the Ammer River located in Alpine southern Germany applying the hydrological simulation model called the Water Flow and Balance Simulation Model (WaSiM). The results show that WaSiM reasonably reproduces the observed runoff for the entire catchment when driven with observed precipitation. When applied with CORDEX evaluation data (1989-2008) forced by ERA-Interim, the simulations underestimate the extreme runoff and reproduce the high percentile values with errors in the range from $-37 \%$ to $55 \%$ with an ensemble mean of around $15 \%$. Runs with historical data $1975-2005$ reveal larger errors, up to $120 \%$, with an ensemble mean of around $50 \%$ overestimation. Also, the results show a large spread between the simulations, primarily resulting from deficiencies in the precipitation data. Results indicate future changes for 2071-2100 in the 99.5th percentile runoff value of up to $9 \%$ compared to 1975 2005. An increase in high flows is also supported by flow return periods obtained from a larger sample of highest flows over 50 years, which reveals for 2051-2100 lower return periods for high runoff values compared to 1956-2005. Obtained results are associated with substantial uncertainties leading to the conclusion that CORDEX data at $0.11^{\circ}$ resolution are likely inadequate for driving hydrologic analyses in mesoscale catchments that require a high standard of fidelity for hydrologic simulation performance.
\end{abstract}

\section{Introduction}

Numerous simulations with global Earth system models (ESMs) as well as statistical and dynamical downscaling experiments provide information about the expected future changes in temperature, precipitation, and other climatic variables, based on current knowledge, available simulation techniques, and certain assumptions about the future changes in the key climate drivers. Mountain regions pose special challenges here, as high spatial resolutions are needed to account for the strong climate gradients originating from large elevation differences within short distances. For the Alpine area, Jacob et al. (2014) derived, from the recent

\footnotetext{
Corresponding author: Gerhard Smiatek, gerhard.smiatek@ kit.edu
}

Coordinated Regional Climate Downscaling Experiments (CORDEX) covering the European model domain (EURO-CORDEX; www.euro-cordex.net) based on the representative concentration pathway 4.5 (RCP4.5) scenario, a probable change in annual precipitation of $4 \%-8 \%$ and an increase in the mean annual temperature on the order of 1.9-3.4 K. For total annual precipitation on days with an amount of rain above the 99th percentile value, an increase from $25 \%$ to $60 \%$ was found. Stakeholders, however, ask how these numbers translate into societal impacts, such as the availability of water or the risk of flooding. The key question is how they can be used to enable managers to make decisions about adaptation and mitigation strategies (Fowler et al. 2007).

The scientific aim of this study is to investigate how the available data from the EURO-CORDEX initiative 
employed in a hydrology model (HM) allow reproducing the observed flow duration curves (FDCs) at various gauges of a river located in the Alpine and pre-Alpine area, and what changes in the river flow can be expected under future climate conditions. The exemplarily chosen investigated catchment is, at $600 \mathrm{~km}^{2}$, typical for an Alpine and pre-Alpine headwater catchment. With its complex terrain, fast propagation of the precipitated water into the high streamflows, and susceptibility to flooding, together with the available weather and streamflow monitoring network, it provides a comprehensive environment for such an exercise. This exercise provides an example of an investigation of a scientific basis that, in the context of the impact of climate change and of adaptation strategies, is relevant and its methods are applicable to all Alpine catchments. A further aim is the identification of possible improvements within the entire processing chain.

The application of climate change data ensembles in hydrological impact studies has been the subject of intensive research. Donnelly et al. (2017) investigated the impact of climate change on European hydrology under assumed warmings of $1.5^{\circ}, 2^{\circ}$, and $3^{\circ}$. They found robust increases in high runoff in a warmer world in large parts of Europe, including the Alpine area. Wagner et al. (2017) investigated the impact of climate change on streamflow and hydro power generation in the Alpine area, stating that a shift of runoff toward the winter season might have a positive impact on the electricity sector. The impact on the average annual electricity generation remained unclear. Smith et al. (2014) applied regional climate model (RCM) data from the ENSEMBLES project to study the impact of future climate change on flooding in the Avon catchment, in the United Kingdom. The authors found that there would be an increase in annual flows under the future conditions in 2061-99. Different investigated methods have yielded, however significant variations in magnitude and spread. Alfieri et al. (2015) assessed the flood risk in Europe applying EUROCORDEX RCP8.5 scenario runs and concluded that depending on the future economic growth there would be an increase in flood damage from currently 5.3 billion euros to $20-40$ billion euros in 2050 and to $30-100$ billion euros in 2080. Viganò et al. (2016) applied data from two GCMs to access future changes on river habitat in an Italian Alpine catchment. They conclude for the middle of the century a $60 \%$ decrease in river flow and emphasize the impact of minimum flows on river biota.

The application of input data from RCMs in subsequent hydrological simulations usually suffers from the precipitation bias present in the data. This is especially the case in complex terrain. Gudmundsson et al. (2012) found large uncertainties when modeling the runoff in small catchments, while the mean of all model simulations allowed achieving rather robust predictions. Dang et al. (2017) investigated the impact of climate change on future hydrological extremes in central Vietnam. They found severe limitations to the bias correction procedures when investigating extreme values, and suggested the application of the delta change approach (e.g., Teutschbein and Seibert 2012) in hydrological decision support.

Being a part of the Terrestrial Environmental Observatories (TERENO) pre-Alpine observatory (www.tereno.net; Zacharias et al. 2011; Kiese et al. 2018) the investigated Ammer catchment is subject to intensive research. Potential impacts of climate change on the Ammer catchment has been first investigated by Kunstmann et al. (2004) by downscaling ECHAM4 time slices. Ott et al. (2013) applied a data ensemble at 7-km resolution based on two HMs, two RCMs, and two GCMs to study the potential impact for 2021-50. The resulting ensemble was increased to 10 members by driving one of the applied RCM with three realizations of the ECHAM5 model. The authors concluded a large spread in the resulting input to the HM obtained from dynamical downscaling which required a bias correction. However, they pointed out that bias correction can have a large impact on the results and therefore it is urgent to decrease the biases in RCM simulations. Also, they emphasized the necessity of a multimodel approach in hydrological impact studies.

The present study is such a multimodel approach. It employs the best currently available RCM data ensemble as the input in hydrological simulations and concentrates on the analysis of the FDCs obtained and the estimated changes in the flow return periods.

This paper is structured as follows. Section 2 describes the study area, the applied hydrological model, and the simulated meteorology input used. The results obtained for the present and future climate are presented and discussed in section 3 , and conclusions are drawn in section 4 .

\section{Material and methods}

\section{a. Investigated catchment}

The investigated catchment is the catchment of the Ammer River located in the Bavarian Ammergau Alps and Alpine foreland, Germany. Its size is around $600 \mathrm{~km}^{2}$ and its elevations range from $500 \mathrm{~m}$ MSL in the northern flat part, with an annual mean precipitation of $1100 \mathrm{~mm}$, to $2185 \mathrm{~m}$ MSL in the mountainous 


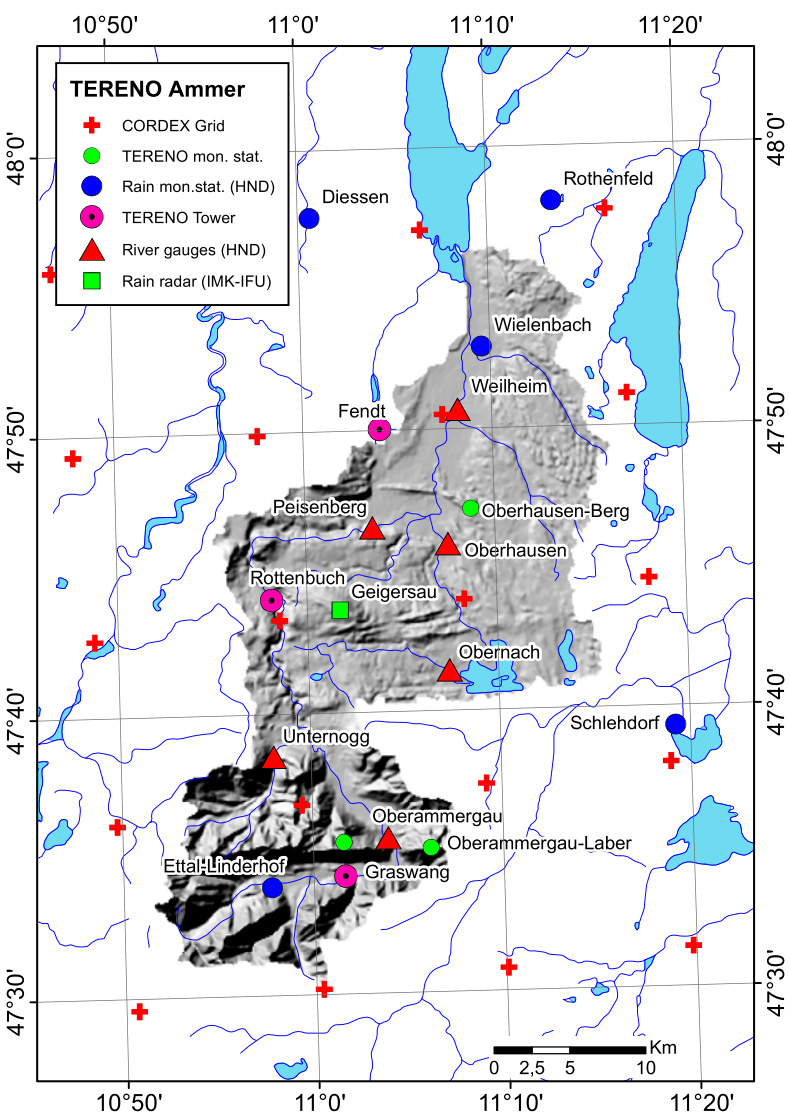

FIG. 1. Investigated catchment of the Ammer River, observational network, and RCM grid cells from an example EUROCORDEX simulation.

southern part, which receives a mean precipitation of around $2000 \mathrm{~mm}$. Interflow is the main component of the runoff across all seasons.

Figure 1 depicts the relief of the catchment and available precipitation and streamflow monitoring stations. The observations are from the TERENO infrastructure, containing temperature, precipitation, wind speed, solar radiation and air humidity. The Hochwasser Nachrichtendienst Bayern (HND) provided precipitation and river runoff, and the Deutscher Wetterdienst (DWD) additional precipitation data. Smiatek et al. (2012) give a detailed description of a coupled precipitation-river runoff forecasting for the Ammer River catchment.

Severe flooding occurred in the area in 1999 and 2005, with the highest flows since 1970 and return periods over 100 years when partially extreme precipitation of over $150 \mathrm{~mm}$ had fallen on already saturated soils. Large area flooding typically can be related to $\mathrm{Vb}$ cyclones. Locally in the flat northern parts, however, there are also floodings caused by stationary convective storms.
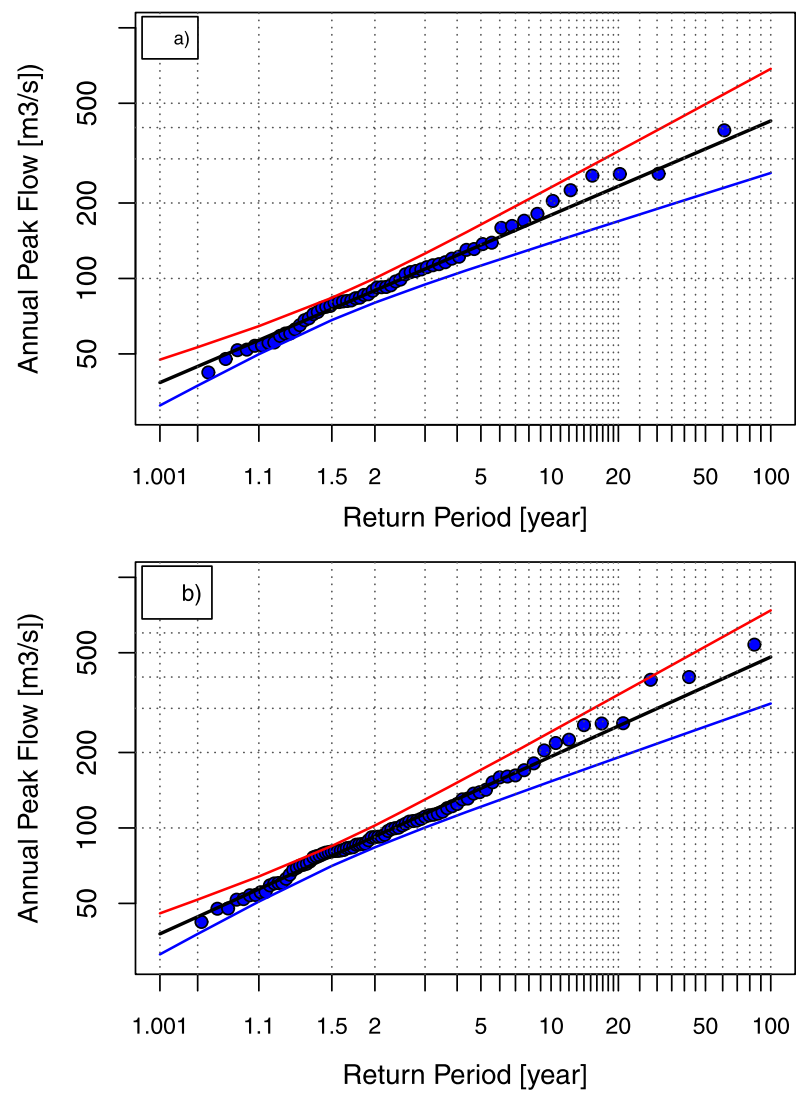

FIG. 2. Flow return periods for the Ammer River at the Weilheim gauge derived from observed discharge (a) 1931-90 and (b) 1961-2016. Lines in blue and red indicate the $95 \%$ confidence level.

Figure 2 shows the calculated flow return periods based on an extreme value type 3 distribution (EVIII) for 1931-60 and 1961-2016. Discharges with a 20-yr return period increased at this gauge from 233 to $255 \mathrm{~m}^{3} \mathrm{~s}^{-1}$.

An analysis of the NWP's predicted and observed precipitation around these events revealed substantial uncertainties in the forecasts, particularly in the timing of the exact location of extreme precipitation events (LFU 2007). In a comparatively small catchment, such uncertainties limit the performance of any flooding forecasting procedure and need special attention in applications with reanalysis and GCM forcings.

\section{b. Employed climate change data input}

The present study employs seven datasets obtained from the EURO-CORDEX downscaling experiments for the RCP4.5 scenario at a horizontal resolution of 0.11 ${ }^{\circ}$. Jacob et al. (2014) and Vautard et al. (2013) describe in detail the EURO-CORDEX experiments. 
TABLE 1. WaSiM simulations and EURO-CORDEX input data employed in the present study. The simulation driven by HadGEM2ES uses a 360-day calendar. Numbers in parentheses denote different realizations of the same driving model. All CORDEX simulations employed the RCP4.5 scenario.

\begin{tabular}{cllllr}
\hline \hline Run & & Institution & \multicolumn{1}{c}{ RCM } & Driving model & Period \\
\hline 1 & cclm & CCLMCOM & CCLM 4.8_17 & MPI-ESM-LR & $1951-2100$ \\
2 & cnrm & CNRM & ALADIN53 & CNRM-CM5 & $1971-2100$ \\
3 & dmi & DMI & HIRHAM5 & NorESM1-M & $1951-2100$ \\
4 & ipsl & IPSL & WRF331F & IPSL-CM5A-MR & $1951-2100$ \\
5 & knmi & KNMI & RACMO22E & EC-EARTH & $1951-2100$ \\
6 & mpi & MPI & REMO2009 & MPI-ESM-LR (2) & $1951-2100$ \\
7 & smhi & SMHI & RCA4 & HadGEM2-ES & $1971-$ October 2099 \\
\hline
\end{tabular}

Table 1 shows the applied RCMs, the driving boundary Coupled Model Intercomparison Project phase 5 (CMIP5) ESM, and the acronyms used to label the hydrology model runs. The central points of the model grid cells from an example for $0.11^{\circ}$ simulation are indicated in Fig. 1. In all, there are 18 different simulations available in EURO-CORDEX. The subset applied in the present study involves all seven available RCMs, each driven with a different boundary input. Because only six driving models were used in the CORDEX experiment, two realizations of the MPI-ESM LR model, the only driving model available in runs of the REMO2009 RCM, were employed, adding up to seven different driving models in all. The choice is justified by the fact that RCM temperature responses tend to cluster according to their driving GCM (Zubler et al. 2016).
The RCM input is interpolated onto the Water Flow and Balance Simulation Model (WaSiM) grid at $100 \mathrm{~m} \times 100 \mathrm{~m}$ resolution applying the inverse distance weighting (IDW) method where the RCM cell center points are considered as artificial monitoring stations. The elevation range of the Ammer catchment is substantially underestimated by 588 $1300 \mathrm{~m}$ in the RCMs. Together with the horizontal grid spacing of approximately $12 \mathrm{~km}$ the applied meteorological driving input is still coarsely resolved. In Alpine catchments, very sharp precipitation gradients occur at short distances that are important to resolve. The EURO-CORDEX simulations cannot fully capture such gradients. Investigating multihourly precipitation extremes Chan et al. (2014) stated that caution is needed in interpretation of $12-\mathrm{km}$ RCM summer extremes. Skamarock (2004) concluded that

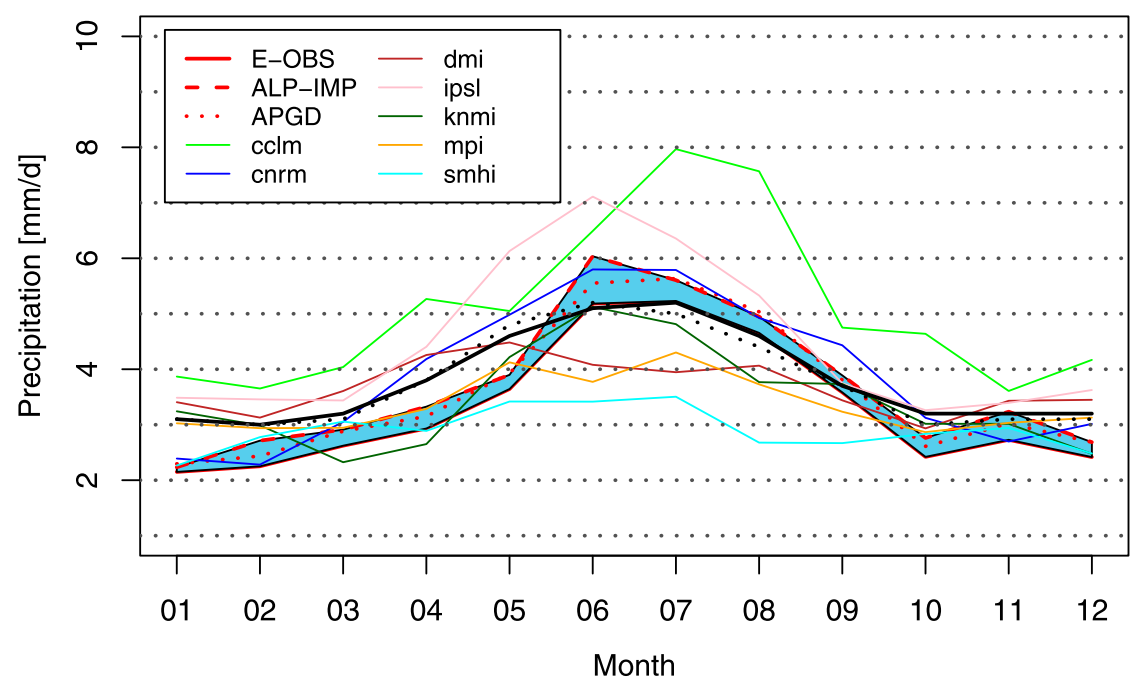

FIG. 3. Observed (E-OBS, ALP-IMP, and EURO4M-APGD) and simulated area mean monthly mean precipitation from historical CORDEX simulations (mm day $\left.{ }^{-1}\right)$ for 1976-2005. The red crosses in Fig. 1 show the CORDEX grid used in the calculation of the area mean. The solid black line indicates the mean of all the CORDEX simulations, and the black dotted line is the mean excluding the cclm and smhi simulations. 


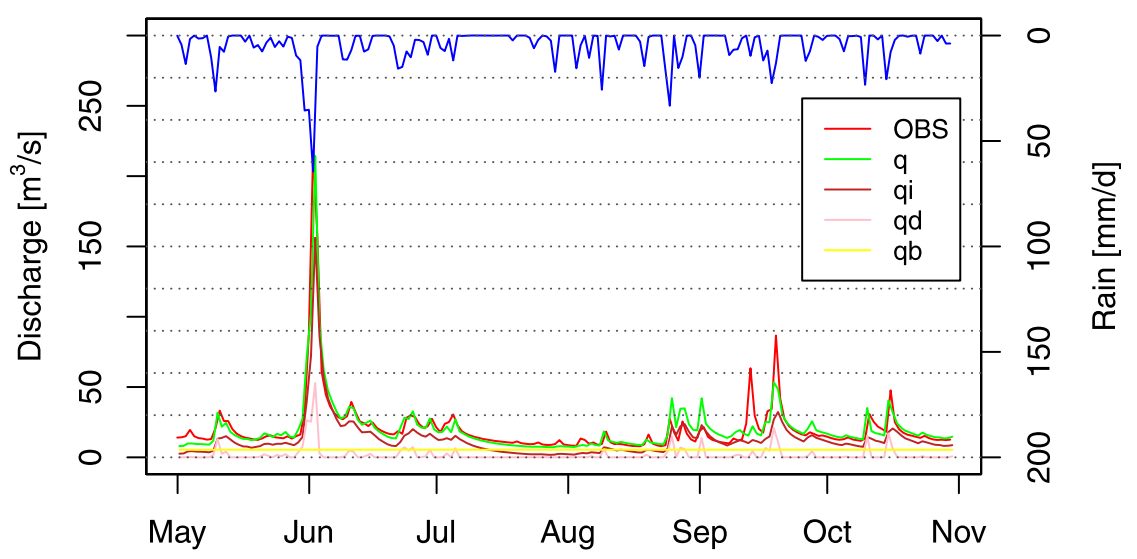

FIG. 4. Observed and simulated daily mean discharge $q$, interflow $q_{i}$, direct flow $q_{d}$, and base flow $q_{b}$ at the Weilheim gauge, and area mean rainfall interpolated from observations for the period 1 May-31 Oct 2016.

effective resolution of an RCM is on the order of 4-8 times its grid spacing. The EURO-CORDEX data resolution is hardly able to fulfill the high-resolution needs for hydrological impact modeling in mesoscale catchments. As it is the best dataset available now, and hydrological decision makers need information on future changes of the water cycle, it is important to investigate its limits and potentials.

The quality of a hydrological simulation depends substantially on the quality of the precipitation data. Not only must the simulation reproduce reasonably well the amount of the precipitation, but also the number of precipitation events, as well as their intensity, duration, spatial structure and orographic effects. Figure 3 shows the area's mean monthly mean observed and simulated precipitation for 1976-2005. The observed reference is from the European daily high-resolution gridded dataset E-OBS Version 14.0 (Haylock et al. 2008; van den Besselaar et al. 2011). For purposes of comparison, the RCM data have been bilinearly remapped to the $0.25^{\circ}$ resolution of the E-OBS dataset. The second observational dataset is from the ALP-IMP (Multicentennial Climate Variability in the Alps, based on Instrumental Data, Model Simulations, and Proxy Data) project of the Climatic Research Unit, Norwich, United Kingdom. It provides data up to 2004. The third dataset is the gridded analysis of daily precipitation in the Alps (APGD; https:// doi.org/10.18751/Climate/Griddata/APGD/1.0; Isotta et al. 2014) at $5 \mathrm{~km} \times 5 \mathrm{~km}$ resolution covering the period 1971-2008. The figure reveals the substantial bias present in the simulated monthly precipitation. Kotlarski et al. (2014) found biases up to $1.5^{\circ} \mathrm{C}$ in the EUROCORDEX seasonally and regionally averaged temperature, and biases in the $\pm 40 \%$ range for precipitation.
Smiatek et al. (2016) evaluated the EURO-CORDEX data for the Greater Alpine Area. The bias in precipitation varied in the Greater Alpine Area between $+14.8 \%$ in summer and $+41.6 \%$ in the winter. Larger errors were found for other statistics, such as the number of wet days, and strong precipitation events over $15 \mathrm{~mm}$ day $^{-1}$.

Thus, any subsequent application of precipitation from RCMs raises the question of a bias correction. Correction of one input entity, even if it is the most important, violates the physics of the system and disturbs the interaction between the meteorological variables. In an ensemble assessment of flood risk in Europe, Alfieri et al. (2015) summarized the limitations of bias correction, stating that there was a violation of the energy balance and insufficient correction of extreme values. They successfully employed raw RCM output in the analysis of return periods of extreme discharge peaks. Maraun (2013) points out that in the case of a large difference in resolution of the observed and modeled data, the commonly applied quantile mapping overestimates the area's mean extremes and overcorrects the drizzle effects. Dang et al. (2017) investigated various bias correction procedures in hydrometeorological modeling for central Vietnam and concluded that they had limited ability to reproduce extreme low and high flows. Frei et al. (2018) investigated the future snowfall in the Alps based on EURO-CORDEX data, finding that percentage changes are robust with respect to the application of raw or bias adjusted snowfall amount. The available record length from the TERENO activity is too short to be employed in a bias correction procedure. On the other hand, the quality of the E-OBS or APGD observations on such small scales appears also questionable 
(Prein and Gobiet 2017) and bias correction might introduce additional errors. Therefore, in the present study, bias correction is omitted.

Besides the results obtained from the individual simulations, two ensemble mean values are also investigated. The first involves all applied models (black line in Fig. 3) while the second ensemble excludes the two models cclm and smhi, depicting the largest sum of squared differences from the E-OBS monthly mean reference data (dotted black line in Fig. 3). Zubler et al. (2016) emphasize that the methods of model selection considerably influence the resulting spread of the data ensemble.

\section{c. The distributed hydrological model}

The applied hydrological model is WaSiM, version 9.9.1 (Schulla 2017). WaSiM is a deterministic, distributed model that applies physically based algorithms for the majority of the process descriptions. The model was run at $100 \mathrm{~m} \times 100 \mathrm{~m}$ resolution at a daily time step with the infiltration approach, after Green and Ampt (1911). The estimation of the saturation time is after Peschke (1987), and it uses translation-retention and kinematic wave approaches in the lateral runoff aggregation. In the application with daily input data, the potential evapotranspiration has been calculated following the approach of Hamon (Hamon 1961).

In the setup of the present experiment, land cover data from the Coordination of Information on the Environment (CORINE) database at 100-m spatial resolution were included in the WaSiM/Ammer River simulation system by updating the spatial data coverage and the related parameter table in the WaSiM control file. A comparable soil map is not yet available for the Ammer area. Thus, a soil map using six texture categories from the previously applied WaSiM version, version 6.4 (Smiatek et al. 2012), was adjusted to the employed version of the model, which is version 9.9.1.

WaSiM was calibrated taking the observed precipitation input and monitored discharge rates at stations indicated in Fig. 1. The calibrated parameters for each basin were: scaling parameter for interflow and recession parameters for direct, inter-, and base flows; fraction of surface runoff on snowmelt; and the recession constant for the saturated hydraulic conductivity with increasing soil depth.

Observed meteorology input plays a critical role in the complex terrain. Prein and Gobiet (2017) showed that gridded E-OBS data are not able capture extreme precipitation and found that observational uncertainties in gridded datasets can be on the same order of magnitude as RCM biases. With the TERENO
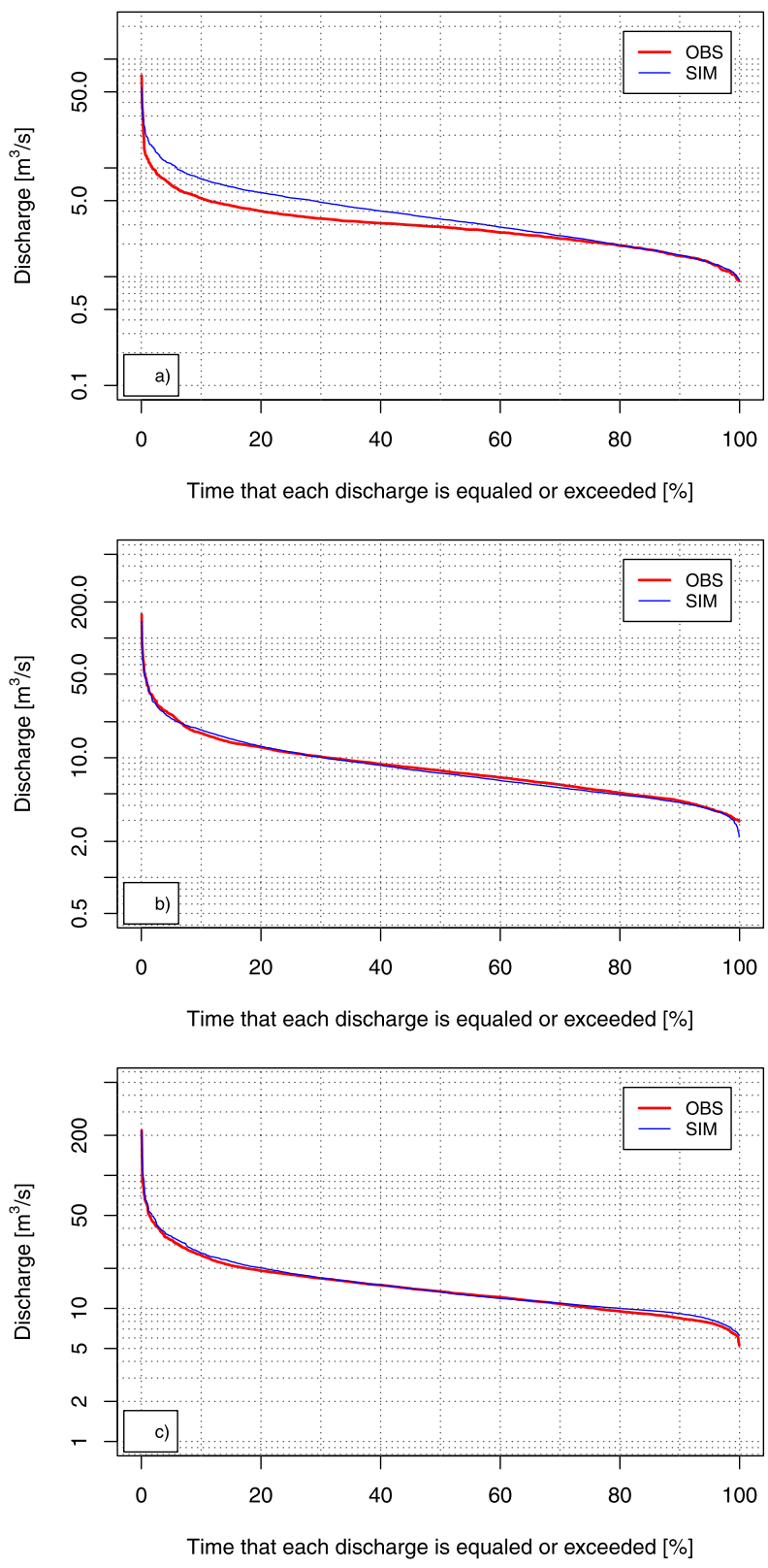

FIG. 5. Observed and simulated FDCs of daily mean runoff 1 Nov 2011-31 Oct 2016. The simulation was performed with observed meteorology input from the observational network as shown in Fig. 1: (a) Oberammergau, (b) Peissenberg, and (c) Weilheim.

infrastructure a unique observational reference for setup and calibration of WaSiM is available within the catchment. TERENO meteorological data were combined with public monitoring network data and applied in WaSiM using IDW gridding.

Figure 4 depicts the observed and simulated discharge at the Weilheim gauge for the calibration period from 1 May to 31 October 2016. The obtained 
TABLE 2. Selected percentile values of the observed and the simulated with observed meteorological input of the Ammer River discharge $\left(\mathrm{m}^{3} \mathrm{~s}^{-1}\right)$ for the period 1 Nov 2011-31 Oct 2016.

\begin{tabular}{|c|c|c|c|c|c|c|c|c|c|}
\hline Gauge & Run & $\begin{array}{c}1 \mathrm{st} \\
\text { percentile }\end{array}$ & $\begin{array}{c}5 \text { th } \\
\text { percentile }\end{array}$ & $\begin{array}{c}50 \text { th } \\
\text { percentile }\end{array}$ & $\begin{array}{c}\text { 90th } \\
\text { percentile }\end{array}$ & $\begin{array}{c}\text { 95th } \\
\text { percentile }\end{array}$ & $\begin{array}{c}\text { 99th } \\
\text { percentile }\end{array}$ & $\begin{array}{c}99.5 \text { th } \\
\text { percentile }\end{array}$ & Maximum \\
\hline \multirow[t]{2}{*}{ Oberammergau } & OBS & 1.0 & 1.3 & 2.9 & 5.3 & 6.9 & 12.1 & 14.5 & 70.7 \\
\hline & SIM & 1.1 & 1.4 & 3.4 & 7.9 & 10.8 & 18.9 & 23.7 & 54.9 \\
\hline \multirow[t]{2}{*}{ Peissenberg } & OBS & 3.1 & 3.8 & 7.8 & 16.0 & 22.9 & 40.3 & 51.1 & 157.6 \\
\hline & SIM & 3.0 & 3.7 & 7.4 & 17.1 & 21.2 & 41.5 & 48.8 & 137.8 \\
\hline \multirow[t]{2}{*}{ Weilheim } & OBS & 6.5 & 7.8 & 13.4 & 25.0 & 32.7 & 57.8 & 69.1 & 218.2 \\
\hline & SIM & 6.9 & 8.3 & 13.3 & 26.1 & 34.9 & 60.2 & 72.8 & 214.4 \\
\hline
\end{tabular}

Nash-Sutcliffe coefficients for this period were 0.82 at Weilheim, 0.83 at Peissenberg, and 0.8 at the Oberammergau gauge. FDCs derived from runs with observed meteorological input for the verification period from 1 November 2011 to 31 October 2016 are shown in Fig. 5. The observed percentile values for the entire investigated catchment at the Weilheim gauge are reproduced with an error ranging from around $6.7 \%$ for the 95 th percentile to $-1.7 \%$ for the maximum (see Table 2). In the Peissenberg subcatchment, the bias ranges from $6.9 \%$ for the 90th percentile to $-12.6 \%$ for the maximum. In the complex terrain of the Oberammergau subcatchment, the biases are larger, and range from a $-22.3 \%$ underestimation of the maximum value to a $63.4 \%$ overestimation of the 99.5 th percentile. In the complex terrain of the study region and with the limited observational data, it is difficult to catch the very extreme values. Furthermore, some drainage to the neighboring catchments can be expected in the calcarious rock environment of the upper Ammer. Overall, the applied hydrological model reproduces the observations reasonably well, albeit potential for improvement remains, especially in the upper part of the catchment.

\section{d. Hydrology model runs}

The hydrological model was driven with meteorological input from the seven applied RCMs for the period from 1 January 1951 to 31 December 2100, with the exception of the cnrm run, which started in 1971, and the smhi run, which started in 1971 and ended on 31 October 2099. Table 1 shows the acronyms and the details of the simulations. The investigated periods are from 1 November 1955 (and 1 November 1975) to 31 October 2005 for the historical runs, allowing for several years of spinup time. The climate change runs are from 1 November 2006 to 31 October 2100, all employing the RCP4.5 scenario. In addition, seven simulations driven with CORDEX evaluation data forced by ERA-Interim, covering the period from 1 November 1989 to 31 October 2008, were analyzed. These runs were initialized at 1 January 1989 and are denoted with the same acronyms, but with an $e$ in the subscript.

\section{Results}

\section{a. Present-day climate}

The severe flooding events in May 1999 and August 2005 already mentioned in section 2 affected large parts of the Bavarian pre-Alpine area. In both events, warm and moist air masses of a low pressure system that took up a large amount of humidity over the northern part of the Mediterranean were advected from the northern direction and with high velocity against the Alps, causing extreme precipitation of up to $330 \mathrm{~mm}$ in $72 \mathrm{~h}$ (LFU 2007). In the Ammer River area, precipitation amounts of up to $166 \mathrm{~mm}$ in $72 \mathrm{~h}$ led to the highest ever measured daily mean discharge rates: $539.4 \mathrm{~m}^{3} \mathrm{~s}^{-1}$ at the Weilhem gauge, $288.9 \mathrm{~m}^{3} \mathrm{~s}^{-1}$ at the Peissenberg gauge, and $136.0 \mathrm{~m}^{3} \mathrm{~s}^{-1}$ at the Oberammergau gauge, on 21 May 1999. In August 2005 , the discharge rates reached values of $400 \mathrm{~m}^{3} \mathrm{~s}^{-1}$ at Weilheim, $236.9 \mathrm{~m}^{3} \mathrm{~s}^{-1}$ at Peissenberg, and $126.8 \mathrm{~m}^{3} \mathrm{~s}^{-1}$ at Oberammergau.

Figure 6 shows the FDCs obtained with meteorology driving from CORDEX evaluation runs with ERA-Interim boundary forcing. The considered time period is from 1 November 1989 to 31 October 2008. All simulations reproduce reasonably well the observed FDCs, but significantly fail to reproduce the observed maximum values (Table 3 ). Furthermore, the simulations exhibit maxima in different years and not in the periods with the observed extreme flows, in 1999 and 2005. It is obvious that the driving ERAInterim reanalysis provides only the large scale meteorological situation; the models have some degrees of freedom and therefore do not necessarily reproduce the observed weather patterns.

The bias in the reproduction of the 99.5th percentile values ranges between $-37 \%$ and $+53 \%$ at Weilheim and between $-15 \%$ and $34 \%$ at Peissenberg. In the Oberammergau subcatchment, the biases are within the range from $10 \%$ to $55 \%$. In this area, all the 

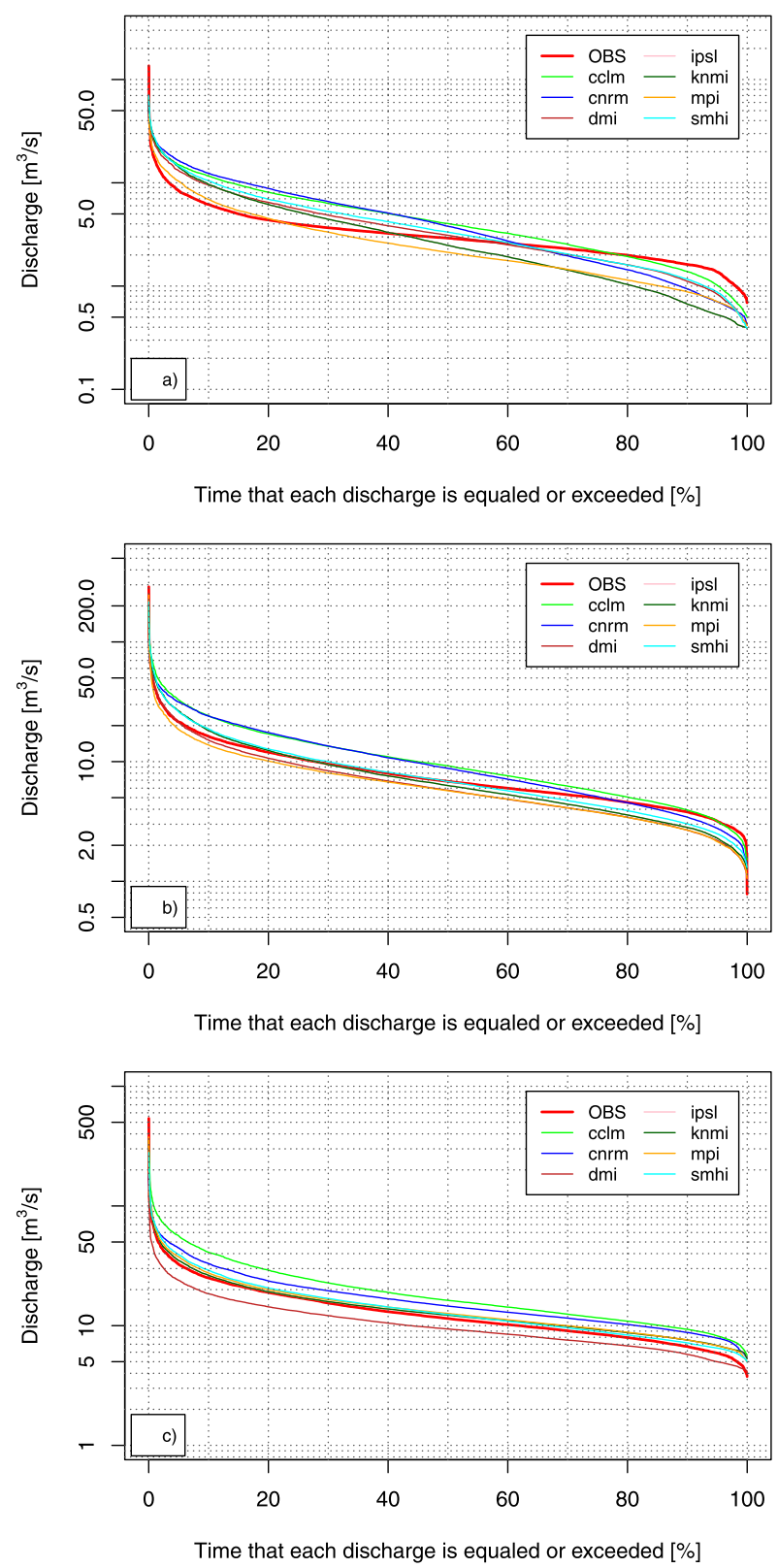

FIG. 6. Observed and with CORDEX evaluation data driven by ERA-Interim simulated FDCs of daily mean runoff 1 Nov 1989-31 Oct 2008 for (a) Oberammergau, (b) Peissenberg, and (c) Weilheim.

simulations overestimate the low and underestimate the high percentiles. The corresponding ensemble mean biases for the three gauges are $15.5 \%, 15.2 \%$, and $38 \%$, indicating a reasonable simulation of the considered high percentiles. The ensemble mean biases in the reproduction of the value of the 99th percentile are of the same order. Similar results arise when excluding the simulations cclm and smhi, those with the highest precipitation biases (in the historical simulation).
The errors in the timing of the precipitation and in its intensity aggravate the hydrological application. An analysis of the observed and simulated precipitation in the area shows that there is a substantial underestimation of specific indices, such as wet days and strong precipitation events, especially in summer. With the exception of the cclm data, an underestimation of the precipitation intensity on wet days by up to $33 \%$ with an ensemble mean of $20 \%$ compared to the E-OBS reference is present. Two models, cclm and ipsl, overestimate the strong precipitation events by more than 10 and $20 \mathrm{~mm}$ day $^{-1}$ throughout the year. All other models here show a substantial underestimation in the summer and a small to moderate overestimation in the other seasons. In the summer, the ensemble mean values are underestimations of the precipitation events by more than $10 \mathrm{~mm} \mathrm{day}^{-1}$, that is, around $12 \%$. The number of events of more than $20 \mathrm{~mm} \mathrm{day}^{-1}$ is underestimated by up to $25 \%$. The considered period is 1976-2005. It has, however, to be stated that over the Alps, gridded datasets systematically underestimate large precipitation intensities (Isotta et al. 2014). Investigating CORDEX simulations, Prein et al. (2016) found in the German Alpine area an underestimation of extreme precipitation above the 97.5 th percentile by about $15 \%-25 \%$ in the summer. A comparison of the simulated extreme precipitation of the Ammer catchment with the rain gauge measurements at the Hohenpeissenberg monitoring station indicates for the ensemble mean an underestimation of the number of rain events above $15 \mathrm{~mm}^{\text {day }}{ }^{-1}$ by $28 \%$. This station is at an elevation of $977 \mathrm{~m}$. While this might be not representative for the entire catchment, it reveals that due to errors in the precipitation amount and timing, an analysis of extreme discharges remains challenging. In summary, it has to be concluded that due to biases in the precipitation input and model deficiencies an analysis of the 99th and 95.5th discharge percentiles constitutes the upper limit in the present investigation.

Table 4 shows the percentile values derived with input data from historical CORDEX runs for the period from 1 November 1975 to 31 October 2005. These WaSiM runs reveal larger runoff biases than the runs with CORDEX validation data. At the gauge Weilheim, the observed 99th and 99.5th percentiles are overestimated by from $11 \%$ to almost $120 \%$, with an ensemble mean of around $54 \%$. At the gauge Peissenberg, the biases range from a small underestimation by $2 \%$ to an overestimation by $111 \%$. The ensemble mean bias is here around $48 \%$ for both percentiles. At the gauge Oberammergau, the overestimation is $70 \%$ for the 99th percentile and $63 \%$ for the 99.5 th percentile. 
TABLE 3. Observed (OBS) and simulated percentile values of the Ammer River discharge $\left(\mathrm{m}^{3} \mathrm{~s}^{-1}\right)$ for 1 Nov 1989-31 Oct 2008. Simulations with CORDEX evaluation data run with ERA-Interim input. Run acronyms are explained in Table 1.

\begin{tabular}{|c|c|c|c|c|c|c|c|c|c|}
\hline Gauge & Run & $\begin{array}{c}1 \text { st } \\
\text { percentile }\end{array}$ & $\begin{array}{c}5 \text { th } \\
\text { percentile }\end{array}$ & $\begin{array}{c}50 \text { th } \\
\text { percentile }\end{array}$ & $\begin{array}{c}\text { 90th } \\
\text { percentile }\end{array}$ & $\begin{array}{c}\text { 95th } \\
\text { percentile }\end{array}$ & $\begin{array}{c}\text { 99th } \\
\text { percentile }\end{array}$ & $\begin{array}{c}\text { 99.5th } \\
\text { percentile }\end{array}$ & Maximum \\
\hline \multirow[t]{8}{*}{ Oberammergau } & OBS & 0.9 & 1.4 & 2.9 & 6.2 & 8.4 & 16.8 & 21.0 & 136.0 \\
\hline & $\operatorname{cclm}_{e}$ & 0.6 & 1.0 & 4.0 & 11.6 & 14.9 & 24.4 & 29.7 & 66.7 \\
\hline & $\mathrm{cnrm}_{e}$ & 0.5 & 0.7 & 3.8 & 12.4 & 16.4 & 25.9 & 31.1 & 59.5 . \\
\hline & $\mathrm{dmi}_{e}$ & 0.5 & 0.8 & 3.1 & 9.5 & 13.1 & 23.8 & 28.6 & 52.8 \\
\hline & $\operatorname{ipsl}_{e}$ & 0.6 & 0.9 & 3.3 & 8.8 & 11.6 & 22.0 & 25.7 & 61.7 \\
\hline & $\mathrm{knmi}_{e}$ & 0.4 & 0.5 & 2.5 & 9.6 & 14.2 & 25.2 & 32.6 & 67.1 \\
\hline & $\mathrm{mpi}_{e}$ & 0.5 & 0.7 & 2.1 & 6.9 & 10.4 & 18.9 & 23.1 & 45.9 \\
\hline & $\operatorname{smhi}_{e}$ & 0.5 & 0.9 & 3.3 & 10.5 & 14.5 & 27.2 & 31.9 & 70.0 \\
\hline \multirow[t]{8}{*}{ Peissenberg } & OBS & 2.5 & 3.2 & 6.8 & 16.3 & 21.5 & 41.3 & 54.3 & 288.9 \\
\hline & $\operatorname{cclm}_{e}$ & 2.2 & 3.2 & 9.2 & 24.1 & 32.7 & 58.7 & 72.7 & 205.2 \\
\hline & $\mathrm{cnrm}_{e}$ & 2.0 & 2.8 & 8.8 & 24.0 & 31.5 & 49.7 & 58.1 & 104.5 \\
\hline & $\mathrm{dmi}_{e}$ & 1.5 & 2.2 & 5.8 & 15.1 & 21.4 & 42.6 & 56.7 & 166.9 \\
\hline & $\mathrm{ipsl}_{e}$ & 2.0 & 2.9 & 8.2 & 21.5 & 29.5 & 59.4 & 72.7 & 209.9 \\
\hline & $\mathrm{knmi}_{e}$ & 1.6 & 2.3 & 6.3 & 18.2 & 26.5 & 50.6 & 62.3 & 181.9 \\
\hline & $\mathrm{mpi}_{e}$ & 1.5 & 2.1 & 5.7 & 13.8 & 18.6 & 34.7 & 46.4 & 249.1 \\
\hline & smhi $_{e}$ & 1.8 & 2.5 & 6.8 & 18.8 & 26.1 & 52.9 & 68.8 & 216.5 \\
\hline \multirow[t]{8}{*}{ Weilheim } & OBS & 4.7 & 5.9 & 11.5 & 25.0 & 32.6 & 60.9 & 77.8 & 539.4 \\
\hline & $\operatorname{cclm}_{e}$ & 6.7 & 8.2 & 16.3 & 41.0 & 56.3 & 94.4 & 119.1 & 354.8 \\
\hline & $\mathrm{cnrm}_{e}$ & 6.1 & 7.9 & 14.6 & 33.0 & 44.5 & 69.2 & 89.0 & 185.7 \\
\hline & $\mathrm{dmi}_{e}$ & 4.4 & 5.0 & 9.4 & 18.4 & 23.9 & 39.8 & 48.9 & 130.2 \\
\hline & $\mathrm{ipsl}_{e}$ & 6.2 & 7.6 & 14.3 & 33.6 & 46.1 & 83.6 & 108.6 & 283.0 \\
\hline & $\mathrm{knmi}_{e}$ & 6.1 & 6.8 & 12.2 & 26.4 & 35.0 & 63.3 & 82.3 & 184.3 \\
\hline & $\mathrm{mpi}_{e}$ & 5.8 & 6.8 & 12.6 & 27.5 & 37.5 & 68.3 & 94.0 & 377.0 \\
\hline & smhi $_{e}$ & 5.6 & 6.5 & 12.4 & 29.1 & 39.3 & 71.6 & 87.0 & 279.9 \\
\hline
\end{tabular}

The range in the single simulations is from $13 \%$ to $102 \%$.

The observed and simulated cumulative kernel densities of the daily mean runoff derived from all performed simulations 1 November 1975-31 October 2005 are shown in Fig. 7. The kernel densities were calculated employing the $\mathrm{R}$ package ks (Duong 2018). The results for the historical period reveal a moderate overestimation of all investigated percentiles at the Weilheim gauge, a small underestimation of the lower percentile values and a moderate overestimation of the high percentiles at Peissenberg, as well as a substantial underestimation of the low percentiles and an overestimation of the high percentiles at Oberammergau. The maximum values are underestimated in all investigated catchments (Fig. 7). These findings indicate that the simulation results, especially in the complex terrain of the southern part of the catchment, may not only suffer from shortcomings in the timing and amount of the CORDEX precipitation, but also from the limitations of the applied modeling system.

\section{b. Future climate}

For the Greater Alpine Area 2071-2100, EUROCORDEX simulations indicate ensemble mean increases in the seasonal mean $2 \mathrm{~m}$ temperature of $2.5^{\circ} \mathrm{C}$ in fall and winter, $2.4^{\circ} \mathrm{C}$ in summer, and $1.9^{\circ} \mathrm{C}$ in spring, when compared to 1971-2000. In the same area, precipitation is simulated to increase by up to $12.3 \%$ in winter and $5.7 \%$ in spring, with only small changes in the fall and summer for the predicted ensemble mean: $+2.3 \%$ and $-1.7 \%$, respectively (Smiatek et al. 2016). For central Europe, Rajczak and Schär (2017) investigated a large ensemble of EURO-CORDEX models, concluding that extreme precipitation events are projected to intensify, especially in winter and fall, by more than $20 \%$.

For the Ammer area, the ensemble mean value of the seven models applied indicates precipitation increases in all seasons: by $+10 \%$ in winter, $7 \%$ in spring, and around $5 \%$ in summer and fall for the period 1 November 207031 October 2100 compared to the period from 1 November 1976 to 31 October 2005. Also, the number of wet days with precipitation about $1 \mathrm{~mm}$ day $^{-1}$ is simulated to increase in eight of the months. However, the simulated changes are rather small. They range from a decrease on the order of $6 \%$ to an increase by $3 \%$ with an ensemble mean of $+1 \%$. The simulated increases in the number of strong precipitation events, that is, with precipitation of $20 \mathrm{~mm} \mathrm{day}^{-1}$, are much larger. Six of the seven investigated CORDEX datasets simulate an increase within the range 13\%-32\%. Only the knmi simulation reveals a small decrease, on the 
TABLE 4. Observed (OBS) and simulated percentile values for the period from 1 Nov 1975 to 31 Oct 2005 and from 1 Nov 2070 to 31 Oct 2100. Run acronyms are explained in Table 1.

\begin{tabular}{|c|c|c|c|c|c|c|c|c|c|}
\hline Gauge & Run & Period & $\begin{array}{c}1 \text { st } \\
\text { percentile }\end{array}$ & $\begin{array}{c}5 \text { th } \\
\text { percentile }\end{array}$ & $\begin{array}{c}50 \text { th } \\
\text { percentile }\end{array}$ & $\begin{array}{c}\text { 90th } \\
\text { percentile }\end{array}$ & $\begin{array}{c}\text { 95th } \\
\text { percentile }\end{array}$ & $\begin{array}{c}\text { 99th } \\
\text { percentile }\end{array}$ & $\begin{array}{c}99.5 \text { th } \\
\text { percentile }\end{array}$ \\
\hline \multirow[t]{15}{*}{ Oberammergau } & OBS & 1975-2005 & 1.0 & 1.3 & 2.9 & 6.2 & 8.5 & 16.7 & 20.7 \\
\hline & \multirow[t]{2}{*}{$\mathrm{cclm}$} & 1975-2005 & 0.6 & 0.9 & 5.3 & 14.6 & 19.0 & 30.4 & 35.0 \\
\hline & & 2070-2100 & 0.8 & 1.3 & 5.7 & 14.2 & 18.1 & 29.2 & 33.9 \\
\hline & \multirow[t]{2}{*}{$\mathrm{cnrm}$} & 1975-2005 & 0.4 & 0.5 & 3.3 & 13.8 & 20.1 & 31.5 & 35.7 \\
\hline & & 2070-2100 & 0.5 & 0.6 & 4.6 & 13.8 & 17.9 & 28.8 & 33.5 \\
\hline & \multirow[t]{2}{*}{ dmi } & 1975-2005 & 0.7 & 1.2 & 4.5 & 11.7 & 15.6 & 28.6 & 34.8 \\
\hline & & 2070-2100 & 0.9 & 1.5 & 4.6 & 11.9 & 15.9 & 28.5 & 32.5 \\
\hline & \multirow[t]{2}{*}{ ipsl } & 1975-2005 & 0.4 & 0.6 & 3.6 & 12.0 & 17.1 & 33.4 & 41.8 \\
\hline & & $2070-2100$ & 0.7 & 1.2 & 4.4 & 11.6 & 15.6 & 28.2 & 34.8 \\
\hline & \multirow[t]{2}{*}{ knmi } & 1975-2005 & 0.4 & 0.4 & 2.4 & 12.1 & 17.9 & 29.7 & 34.5 \\
\hline & & $2070-2100$ & 0.4 & 0.5 & 3.0 & 10.5 & 14.1 & 23.5 & 28.5 \\
\hline & \multirow[t]{2}{*}{ mpi } & 1975-2005 & 0.5 & 0.6 & 2.3 & 7.5 & 10.7 & 18.3 & 22.5 \\
\hline & & $2070-2100$ & 0.5 & 0.7 & 2.5 & 7.8 & 10.7 & 19.0 & 23.4 \\
\hline & \multirow[t]{2}{*}{ smhi } & 1975-2005 & 0.5 & 0.8 & 3.8 & 9.9 & 13.4 & 26.2 & 32.4 \\
\hline & & $2070-2100$ & 0.7 & 1.3 & 4.3 & 11.0 & 14.2 & 26.2 & 32.4 \\
\hline \multirow[t]{15}{*}{ Peissenberg } & OBS & 1975-2005 & 2.6 & 3.2 & 6.9 & 16.3 & 21.4 & 39.7 & 49.7 \\
\hline & \multirow{2}{*}{ cclm } & 1975-2005 & 2.6 & 3.7 & 11.6 & 31.1 & 41.0 & 68.7 & 83.3 \\
\hline & & 2070-2100 & 2.7 & 4.1 & 12.1 & 30.9 & 41.7 & 71.2 & 85.0 \\
\hline & \multirow[t]{2}{*}{ cnrm } & 1975-2005 & 1.5 & 1.9 & 8.0 & 26.6 & 34.8 & 55.9 & 63.0 \\
\hline & & $2070-2100$ & 2.0 & 2.7 & 9.9 & 26.8 & 34.3 & 54.5 & 64.8 \\
\hline & \multirow[t]{2}{*}{ dmi } & 1975-2005 & 2.3 & 3.1 & 7.6 & 19.7 & 27.2 & 55.4 & 69.7 \\
\hline & & 2070-2100 & 2.1 & 3.0 & 7.8 & 20.2 & 27.6 & 53.9 & 67.0 \\
\hline & \multirow[t]{2}{*}{ ipsl } & 1975-2005 & 1.7 & 2.6 & 9.2 & 28.5 & 41.6 & 83.8 & 100.6 \\
\hline & & $2070-2100$ & 2.6 & 3.7 & 10.5 & 28.9 & 39.9 & 80.8 & 104.7 \\
\hline & \multirow[t]{2}{*}{ knmi } & 1975-2005 & 1.4 & 1.8 & 6.1 & 21.4 & 31.3 & 59.1 & 70.7 \\
\hline & & 2070-2100 & 1.7 & 2.3 & 6.9 & 18.9 & 25.8 & 50.6 & 63.1 \\
\hline & \multirow[t]{2}{*}{ mpi } & 1975-2005 & 1.5 & 2.1 & 5.9 & 15.1 & 20.6 & 38.8 & 51.7 \\
\hline & & $2070-2100$ & 1.2 & 2.0 & 6.2 & 16.1 & 22.1 & 43.0 & 54.4 \\
\hline & \multirow[t]{2}{*}{ smhi } & 1975-2005 & 2.2 & 3.2 & 8.0 & 19.0 & 25.2 & 50.7 & 64.3 \\
\hline & & 2070-2100 & 2.8 & 3.6 & 8.7 & 21.8 & 28.9 & 54.8 & 71.2 \\
\hline \multirow[t]{15}{*}{ Weilheim } & OBS & 1975-2005 & 5.0 & 6.0 & 11.6 & 24.8 & 32.3 & 59.6 & 74.8 \\
\hline & \multirow[t]{2}{*}{$\operatorname{cclm}$} & 1975-2005 & 7.4 & 9.2 & 19.6 & 56.7 & 76.2 & 125.8 & 154.2 \\
\hline & & $2070-2100$ & 7.2 & 9.3 & 19.8 & 58.8 & 79.9 & 133.5 & 161.8 \\
\hline & \multirow[t]{2}{*}{$\mathrm{cnrm}$} & 1975-2005 & 5.8 & 6.6 & 14.6 & 36.7 & 49.9 & 89.7 & 110.1 \\
\hline & & $2070-2100$ & 6.5 & 7.7 & 16.0 & 40.4 & 54.1 & 99.0 & 116.2 \\
\hline & \multirow[t]{2}{*}{$\mathrm{dmi}$} & 1975-2005 & 5.5 & 6.3 & 11.6 & 25.4 & 34.0 & 66.1 & 82.7 \\
\hline & & $2070-2100$ & 5.2 & 6.2 & 12.0 & 28.0 & 38.3 & 69.0 & 82.6 \\
\hline & \multirow[t]{2}{*}{ ipsl } & 1975-2005 & 6.2 & 7.8 & 16.7 & 46.6 & 64.6 & 130.1 & 154.1 \\
\hline & & $2070-2100$ & 7.1 & 8.7 & 17.5 & 52.1 & 74.2 & 142.6 & 178.9 \\
\hline & knmi & 1975-2005 & 5.4 & 6.2 & 12.0 & 29.3 & 41.7 & 78.7 & 99.8 \\
\hline & & $2070-2100$ & 5.7 & 6.6 & 12.0 & 28.6 & 38.9 & 75.5 & 98.4 \\
\hline & mpi & 1975-2005 & 5.7 & 6.7 & 13.2 & 33.1 & 46.1 & 84.4 & 113.6 \\
\hline & & $2070-2100$ & 5.4 & 6.8 & 13.5 & 36.1 & 51.8 & 98.3 & 125.2 \\
\hline & smhi & 1975-2005 & 6.7 & 8.3 & 14.3 & 30.2 & 40.2 & 71.6 & 90.3 \\
\hline & & 2070-2100 & 7.4 & 8.5 & 15.2 & 36.5 & 49.3 & 86.6 & 107.2 \\
\hline
\end{tabular}

order of $3 \%$ in 2070-2100 compared to 1976-2005. The ensemble mean reveals an increase here of around $17 \%$.

Results of the hydrological simulations for the period from 1 November 2070 to 31 October 2100 are illustrated in Fig. 8 and in Table 4. In the Oberammergau subcatchment, only one run indicates a small increase of the high percentiles. The change in the ensemble mean from that of the period from 1 November 1975 to 31 October 2005 is a decrease on the order of $7 \%$. At Peissenberg, five runs simulate an increase of the high percentiles. For the 99.5th percentile, the simulations yield changes that range from $-10 \%$ to $+11 \%$ with an ensemble mean of $1.4 \%$. The changes in the 99 th percentile range from $-15 \%$ to $11 \%$ with an ensemble mean of $-0.9 \%$. At the Weilheim gauge, the simulations indicate an increase in both investigated percentile values on the order of $9 \%$, 

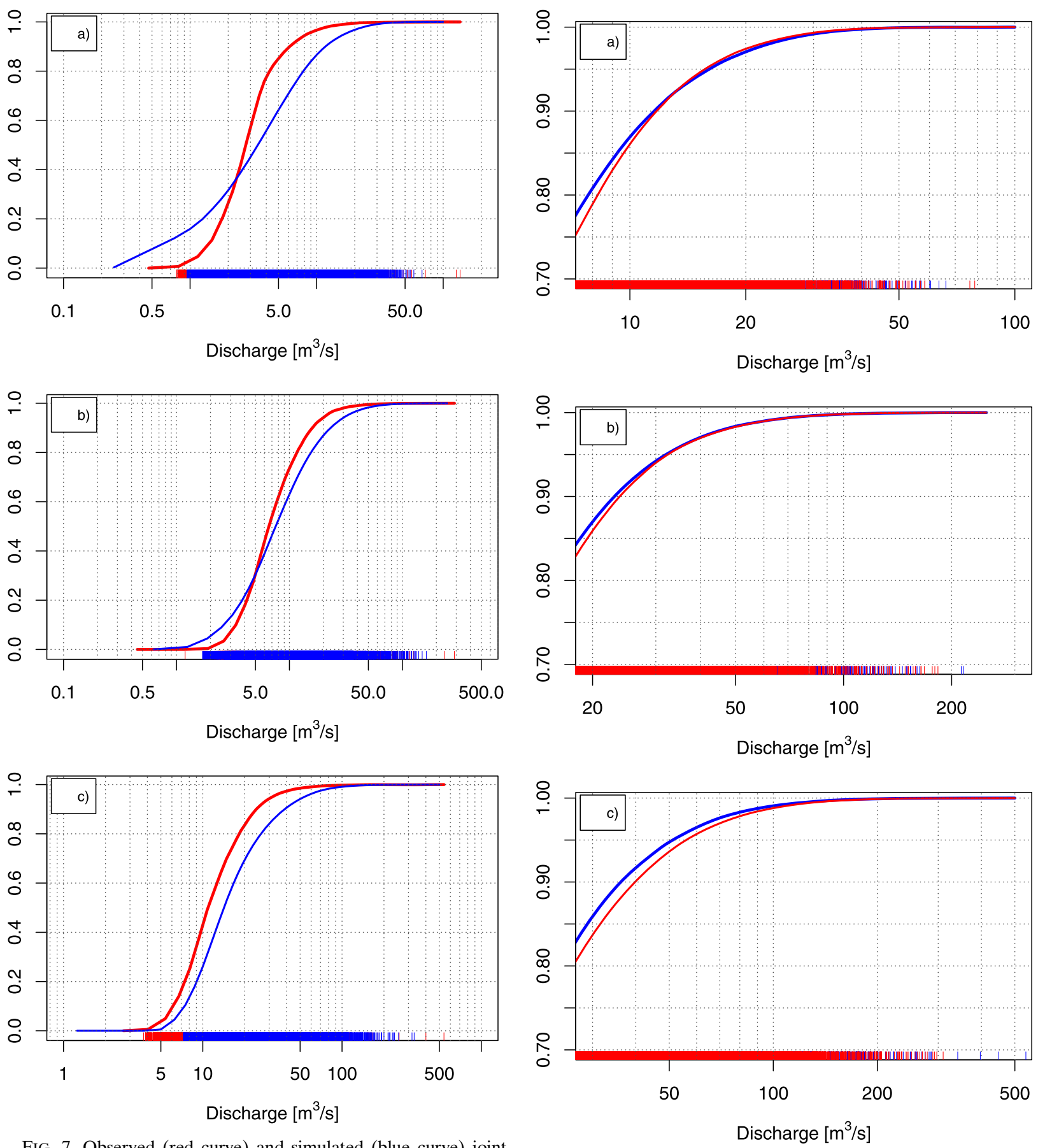

FIG. 7. Observed (red curve) and simulated (blue curve) joint cumulative kernel densities of daily mean runoff 1 Nov 1975-31 Oct 2005 from all simulations listed in Table 1 for (a) Oberammergau, (b) Peissenberg, and (c) Weilheim. The data points compose the rug plot along the $x$ axis.

ranging from $-1 \%$ to $19 \%$ for the 99.5 th percentile and from $-4 \%$ to $18 \%$ for the 99 th percentile.

Figure 9 shows a radar plot illustrating the future changes in the considered percentile values at the Weilheim gauge resulting from all simulations. Six

FIG. 8. Simulated joint cumulative kernel densities of daily mean runoff 1 Nov 1955-31 Oct 2005 (blue curve) and 1 Nov 2050-31 Oct 2100 (red curve) from all simulations listed in Table 1 for (a) Oberammergau, (b) Peissenberg, and (c) Weilheim.

investigated simulations indicate here an increase in the high percentile values. The simulations show a shift in higher percentile values, and on the other hand, the figure reveals large differences between the individual simulations, reaching for example for 

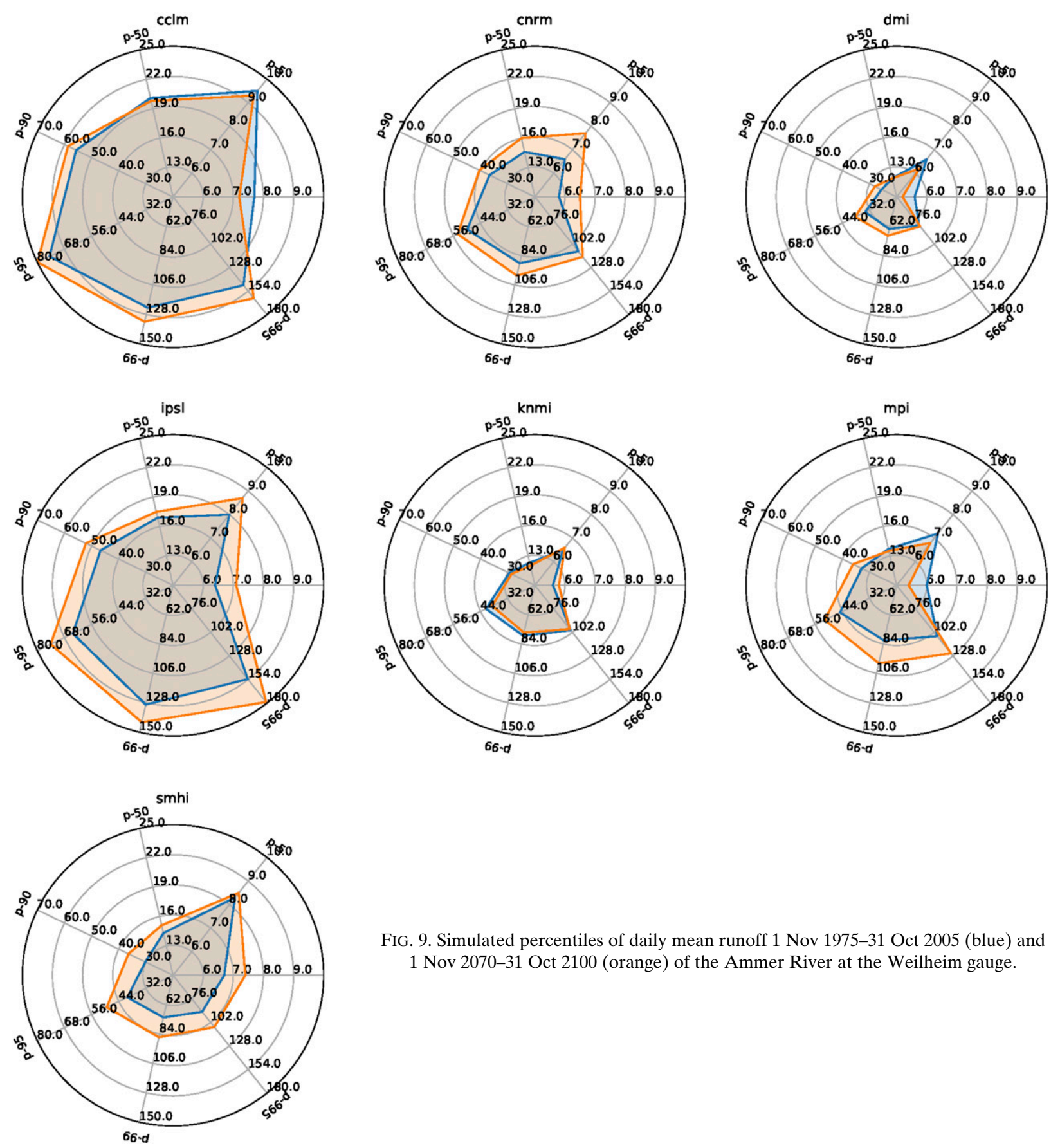

FIG. 9. Simulated percentiles of daily mean runoff 1 Nov 1975-31 Oct 2005 (blue) and 1 Nov 2070-31 Oct 2100 (orange) of the Ammer River at the Weilheim gauge.

the 99.5 th percentile almost $80 \mathrm{~m}^{3} \mathrm{~s}^{-1}$. This indicates a substantial uncertainty in the results, as a consequence of the large differences in the simulated precipitation. In complex terrain, improvements can be expected from higher-resolution simulations with convection-permitting models. Wagner et al. (2018) and Ban et al. (2014) showed that models have to be operated in convection-permitting mode to capture subdaily extreme events in the Alps. With this mode Prein et al. (2013a) reported improved timing of summer convective precipitation and the intensity in most extreme precipitation events. Prein and Gobiet (2017) concluded that a higher model resolution improves the precipitation distribution for daily and three-hourly amounts in Switzerland. Arnault et al. (2018) found improvements in the reproduction of observed daily discharges in central Europe from applying a fully coupled WRF-Hydro model where 

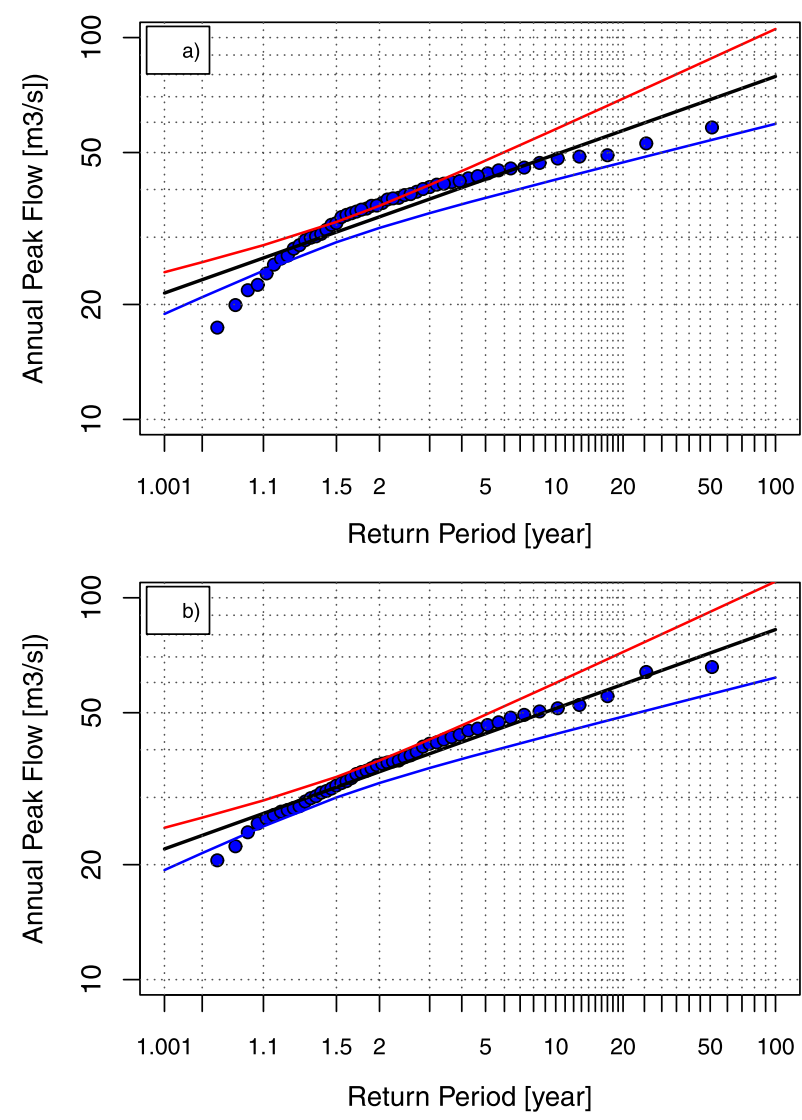

FIG. 10. Simulated ensemble mean flow return periods for the Ammer River at the Oberamergau gauge: (a) 1956-2005 and (b) 20512100. Lines in blue and red indicate the $95 \%$ confidence level.

in a two way coupled approach an extended soilvegetation model is run with much higher spatial and temporal resolution as the meteorology model. Something similar might be the case in the complex terrain of the upper Ammer River.

In spite of an expected increase in high precipitation events, the simulations indicate rather minor changes in the high flow values of the Ammer River. An additional view of this issue provides estimates of the flow return periods depicted in Figs. 10-12. To increase the accuracy, the investigated periods were extended to 50 years. The return periods were derived from the joint cumulative distributions of all model runs. The slope of the FDCs increases slightly in the future period from 2051 to 2100 compared to the period from 1956 to 2005 in all investigated subcatchments. Discharges with a 20 -yr return period increased at the Oberammergau gauge from 57 to $59 \mathrm{~m}^{3} \mathrm{~s}^{-1}$. In Peissenberg the increase in flow is from 156 to $164 \mathrm{~m}^{3} \mathrm{~s}^{-1}$ and in Weilheim from 250 to $254 \mathrm{~m}^{3} \mathrm{~s}^{-1}$.

Additional uncertainties may result from future changes in the catchment vegetation and snowpack which could have a significant effect on the runoff.
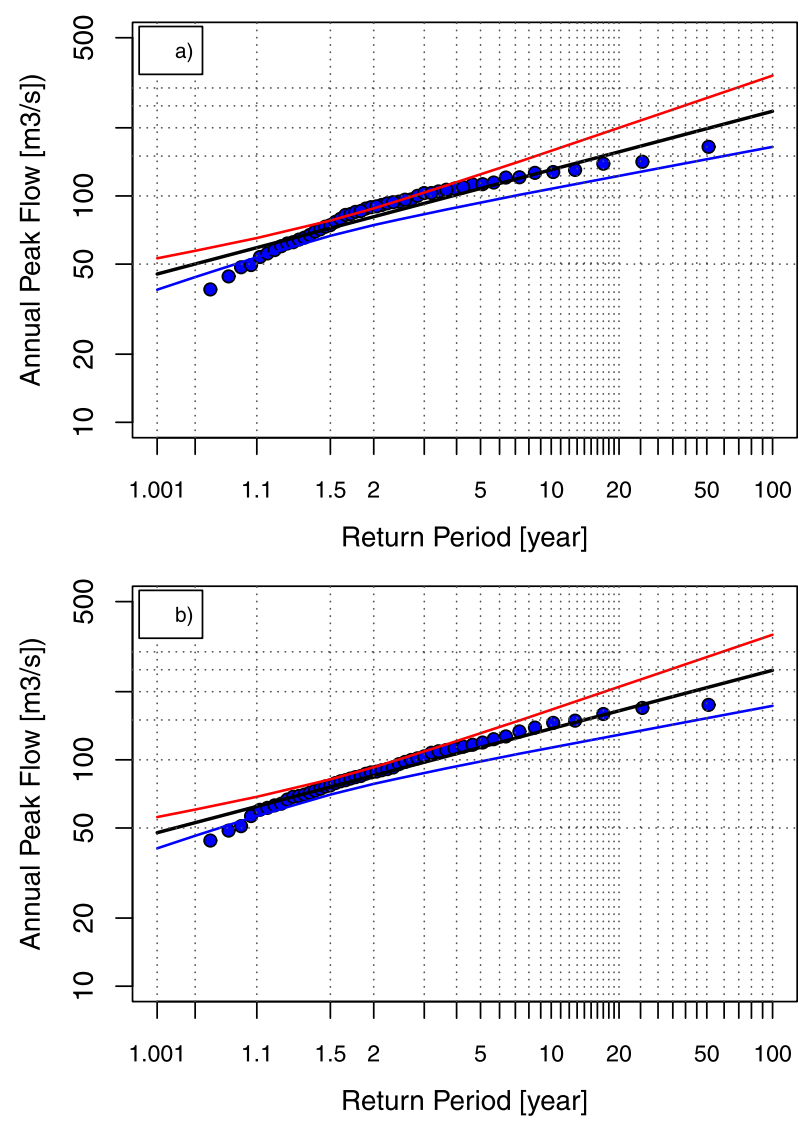

FIG. 11. Simulated ensemble mean flow return periods for the Ammer River at the Peissenberg gauge: (a) 1956-2005 and (b) 20512100. Lines in blue and red indicate the $95 \%$ confidence level.

There are also indications that the subdaily precipitation might change substantially in the future (Kendon et al. 2014; Giorgi et al. 2016; Rasmussen et al. 2019), which could affect extreme runoff in small catchments. In addition, changes in the catchment's soil moisture are important and typically unsatisfactorily modeled.

\section{Conclusions}

The present article investigates reproduction of observed river runoffs and simulated future river runoffs for a complex Alpine terrain catchment using a dataset derived from the distributed hydrology model WaSiM driven with data from the EUROCORDEX experiment. Our analysis has chosen the Ammer catchment as it is a typical example of an Alpine to pre-Alpine headwater catchment, where in parallel via TERRENO infrastructure and previous studies detailed hydrological knowledge and system understanding exists. It extends previous studies by application of the broadest available matrix of RCM 

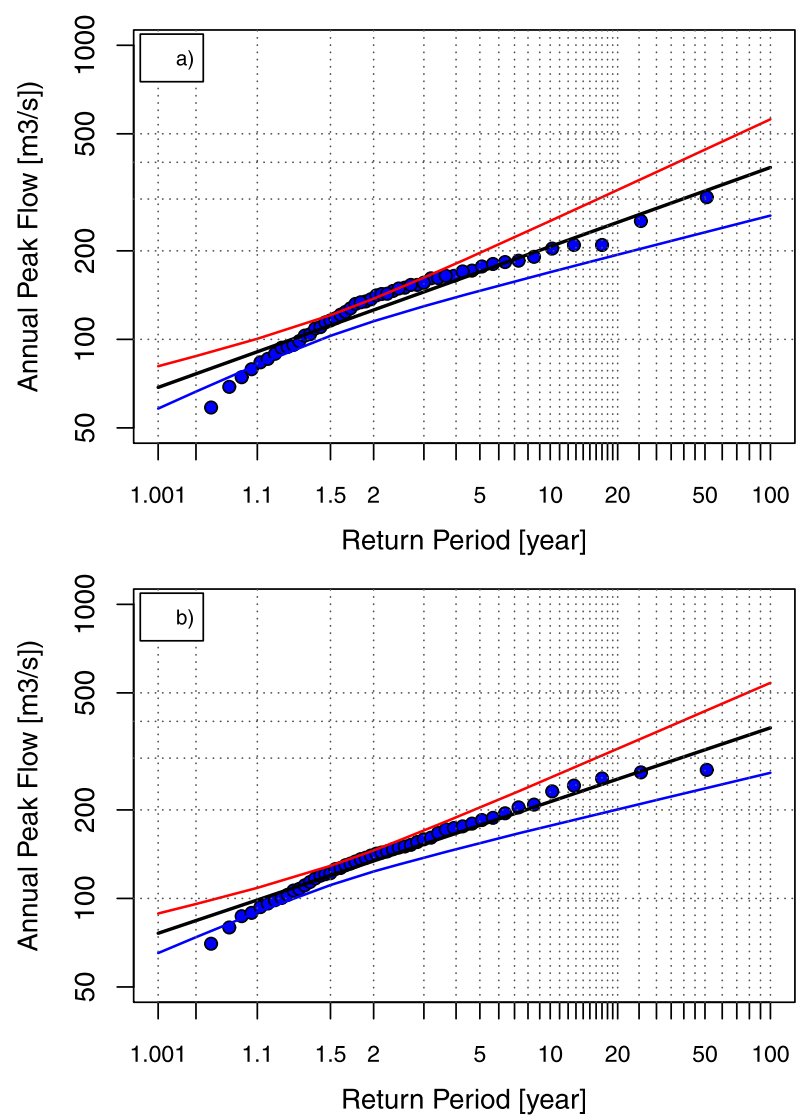

FIG. 12. Simulated ensemble mean flow return periods for the Ammer River at the Weilheim gauge: (a) 1956-2005 and (b) 20512100. Lines in blue and red indicate the $95 \%$ confidence level.

and driving GCM data at $12-\mathrm{km}$ spatial resolution. The simulations employ precipitation, temperature, humidity, wind, and shortwave radiation data at a daily temporal resolution of seven RCMs from the CORDEX evaluation as well as from historical and RCP4.5 experiments without bias correction.

The simulations show that WaSiM reproduces reasonably well the observed runoff of the entire Ammer catchment measured at the Weilheim river gauge when driven with the observed precipitation. The observed flow duration curves are matched reasonably well at the Weilheim gauge and in the Peissenberg subcatchment. Only for the upper Ammer does the system reveal larger errors, up to $60 \%$ in the high percentile values. When used with CORDEX evaluation data (1989-2008), WaSiM underestimates the extreme runoff and reproduces the high percentile values with errors in a range from $-37 \%$ to $55 \%$. The ensemble mean bias in the high percentiles for the entire catchment is around $15 \%$.

Runs with historical data (1975-2005) reveal errors up to $120 \%$ with an ensemble mean of around $50 \%$. The results show a large spread between the simulations, which primarily results from deficiencies in the precipitation data. This makes an analysis of the extreme runoff values with the present investigation design difficult.

The results indicate, however, future changes 20712100 in the 99.5 th percentile runoff value of up to $9 \%$ compared to 1975-2005. An increase in high flows is also supported by the flow return periods obtained from a larger sample of highest flows over 50 years, which reveals for 2051-2100 lower return periods for high runoff values compared to 1956-2005.

These results indicate that the number of high flows might increase and the return periods of high flows decrease in the future. However, a reliable quantification of these changes remains challenging with the presently available data input and the available model systems.

A major source of uncertainty is the substantial bias in the simulated RCM precipitation. Some models fail to reproduce both the amount and the seasonality of the observed precipitation and thus may be unsuitable for hydrologic frequency analysis. It has, however, be taken into account that the EURO-CORDEX data at $12-\mathrm{km}$ resolution is probably still too coarse for Alpine catchments and therefore not able to reproduce the observed precipitation amount, timing and frequency. For that reasons CORDEX data may be inadequate for driving hydrologic analyses, and particularly design studies or applications that require high standard of fidelity for hydrologic simulation performance. In the future, convection-permitting modeling should reduce this bias in the Alpine region. These models are able to capture orographic forced gradients much better and also have an improved representation of deep convection (e.g., Prein et al. 2013a,b; Ban et al. 2014; Chan et al. 2014). Additional uncertainty results from deficiencies in the observational reference especially in catchments with limited number of monitoring stations.

At the present stage these uncertainties can be reduced applying ensemble mean data at daily temporal resolution and limiting the frequency analysis to 99.5th percentiles as maximum.

Future studies with fully coupled atmospherehydrology model system in convection permitting mode may be able to overcome limitations of hydrological climate change impact studies in mountainous terrain identified in present study. Furthermore, it is suggested to include catchment hydrology in the evaluation of future large RCM modeling experiments in well-defined catchments in addition to evaluations against climatology data. Such an exercise can help in all the efforts needed to improve the $\mathrm{RCM} / \mathrm{HM}$ simulations. 
Acknowledgments. The authors are grateful to the World Climate Research Programme's Working Group on Regional Climate, and the Working Group on Coupled Modelling, the former coordinating body of CORDEX and the responsible panel for CMIP5. We also thank the climate modeling groups (listed in Table 1 of this paper) for producing and making available their model output. We also thank the Earth System Grid Federation infrastructure, an international effort led by the U.S. Department of Energy's Program for Climate Model Diagnosis and Intercomparison, the European Network for Earth System modeling, and other partners in the Global Organisation for Earth System Science Portals. The authors acknowledge the E-OBS dataset from the EU-FP6 project ENSEMBLES and the data providers in the ECA\&D project (eca.knmi.nl). The technical infrastructure and data from the TERENO (www.tereno.net) observatory and the use of the RWater script (Purdue University) are gratefully acknowledged.

\section{REFERENCES}

Alfieri, L., L. Feyen, F. Dottori, and A. Bianchi, 2015: Ensemble flood risk assessment in Europe under high end climate scenarios. Global Environ. Change, 35, 199-212, https://doi.org/ 10.1016/j.gloenvcha.2015.09.004.

Arnault, J., and Coauthors, 2018: Precipitation sensitivity to the uncertainty of terrestrial water flow in WRF-Hydro: an ensemble analysis for central Europe. J. Hydrometeor., 19, 10071025, https://doi.org/10.1175/JHM-D-17-0042.1.

Ban, N., J. Schmidli, and C. Schär, 2014: Evaluation of the convection-resolving regional climate modeling approach in decade-long simulations. J. Geophys. Res. Atmos., 119, 78897907, https://doi.org/10.1002/2014JD021478.

Chan, S. C., E. J. Kendon, H. J. Fowler, S. Blenkinsop, N. M. Roberts, and C. A. T. Ferro, 2014: The value of highresolution Met Office regional climate models in the simulation of multihourly precipitation extremes. J. Climate, 27, 6155-6174, https://doi.org/10.1175/JCLI-D-13-00723.1.

Dang, Q. T., P. Laux, and H. Kunstmann, 2017: Future high- and lowflow estimations for Central Vietnam: A hydro-meteorological modelling chain approach. Hydrol. Sci. J., 62, 1867-1889, https:// doi.org/10.1080/02626667.2017.1353696.

Donnelly, C., W. Greuell, J. Andersson, D. Gerten, G. Pisacane, P. Roudier, and F. Ludwig, 2017: Impacts of climate change on European hydrology at 1.5, 2 and 3 degrees mean global warming above preindustrial level. Climatic Change, 143, 13-26, https://doi.org/10.1007/s10584-017-1971-7.

Duong, T., 2018: ks: Kernel Smoothing, version 1.11.5. R package, https://CRAN.R-project.org/package $=\mathrm{ks}$.

Fowler, H. J., S. Blenkinsop, and C. Tebaldi, 2007: Linking climate change modelling to impacts studies: Recent advances in downscaling techniques for hydrological modelling. Int. J. Climatol., 27, 1547-1578, https://doi.org/ 10.1002/joc. 1556 .

Frei, P., S. Kotlarski, M. A. Liniger, and C. Schär, 2018: Future snowfall in the Alps: projections based on the EUROCORDEX regional climate models. Cryosphere, 12, 1-24, https://doi.org/10.5194/tc-12-1-2018.
Giorgi, F., C. Torma, E. Coppola, N. Ban, C. Schär, and S. Somot, 2016: Enhanced summer convective rainfall at Alpine high elevations in response to climate warming. Nat. Geosci., 9, 584-589, https://doi.org/10.1038/ngeo2761.

Green, W. H., and G. Ampt, 1911: Studies in soil physics, I, Flow of air and water through soils. J. Agric. Sci., 4, 1-24, https:// doi.org/10.1017/S0021859600001441.

Gudmundsson, L., T. Wagener, L. M. Tallaksen, and K. Engeland, 2012: Evaluation of nine large-scale hydrological models with respect to the seasonal runoff climatology in Europe. Water Resour. Res., 48, W11504, https://doi.org/10.1029/ 2011WR010911.

Hamon, W. R., 1961: Estimating potential evapotranspiration. J. Hydraul. Div., 87, 107-120.

Haylock, M., N. Hofstra, A. Klein Tank, E. Klok, P. Jones, and M. New, 2008: A European daily high-resolution gridded dataset of surface temperature and precipitation for 1950 2006. J. Geophys. Res. Atmos., 113, 2156-2202, https://doi.org/ 10.1029/2008JD010201.

Isotta, F. A., and Coauthors, 2014: The climate of daily precipitation in the Alps: Development and analysis of a highresolution grid dataset from pan-Alpine rain-gauge data. Int. J. Climatol., 34, 1657-1675, https://doi.org/10.1002/joc.3794.

Jacob, D., and Coauthors, 2014: EURO-CORDEX: New highresolution climate change projections for European impact research. Reg. Environ. Change, 14, 563-578, https://doi.org/ 10.1007/s10113-013-0499-2.

Kendon, E., N. Roberts, H. Fowler, M. Roberts, S. Chan, and C. Senior, 2014: Heavier summer downpours with climate change revealed by weather forecast resolution mode. Nat. Climate Change, 4, 570-576, https://doi.org/10.1038/ nclimate2258.

Kiese, R., and Coauthors, 2018: The TERENO Pre-Alpine Observatory: Integrating Meteorological, Hydrological, and Biogeochemical Measurements and Modeling. Vadose Zone J., 17, https://doi.org/10.2136/vzj2018.03.0060.

Kotlarski, S., and Coauthors, 2014: Regional climate modeling on European scales: A joint standard evaluation of the EUROCORDEX RCM ensemble. Geosci. Model Dev., 7, 1297-1333, https://doi.org/10.5194/gmd-7-1297-2014.

Kunstmann, H., K. Schneider, R. Forkel, and R. Knoche, 2004: Impact analysis of climate change for an Alpine catchment using high resolution dynamic downscaling of ECHAM4 time slices. Hydrol. Earth Syst. Sci., 8, 1031-1045, https://doi.org/ 10.5194/hess-8-1031-2004.

LFU, 2007: Gewässerkundlicher Bericht Hochwasser August 2005 (in German). Tech. Rep., Bayerisches Landesamt für Umwelt, 75 pp., https://media.hnd.bayern.de/berichte/Gewaesserkundl_ Bericht_HW200508.pdf.

Maraun, D., 2013: Bias correction, quantile mapping, and downscaling: Revisiting the inflation issue. J. Climate, 26, 21372143, https://doi.org/10.1175/JCLI-D-12-00821.1.

Ott, I., and Coauthors, 2013: High resolution climate change impact analysis on medium sized river catchments in Germany: An ensemble assessment. J. Hydrometeor., 14, 1175-1193, https://doi.org/10.1175/JHM-D-12-091.1.

Peschke, G., 1987: Soil moisture and runnoff components from a physically founded approach. Acta Hydrophys., 31, 191-205.

Prein, A. F., and A. Gobiet, 2017: Impacts of uncertainties in European gridded precipitation observations on regional climate analysis. Int. J. Climatol., 37, 305-327, https://doi.org/10.1002/joc.4706.

— , and Coauthors, 2016: Precipitation in the EURO-CORDEX $0.11^{\circ}$ and $0.44^{\circ}$ simulations: high resolution, high benefits? 
Climate Dyn., 46, 383-412, https://doi.org/10.1007/s00382-0152589-y.

, A. Gobiet, M. Suklitsch, H. Truhetz, N. K. Awan, K. Keuler, and G. Georgievski, 2013a: Added value of convection permitting seasonal simulations. Climate Dyn., 41, 2655-2677, https://doi.org/10.1007/s00382-013-1744-6.

—, G. J. Holland, R. M. Rasmussen, J. Done, K. Ikeda, M. P. Clark, and C. H. Liu, 2013b: Importance of regional climate model grid spacing for the simulation of heavy precipitation in the Colorado headwaters. J. Climate, 26, 4848-4857, https:// doi.org/10.1175/JCLI-D-12-00727.1.

Rajczak, J., and C. Schär, 2017: Projections of future precipitation extremes over Europe: A multimodel assessment of climate simulations. J. Geophys. Res. Atmos., 122, 10773-10800, https://doi.org/10.1002/2017JD027176.

Rasmussen, K., A. Prein, R. Rasmussen, K. Ikeda, and C. Liu, 2019: Changes in the convective population and thermodynamic environments in convection-permitting regional climate simulations over the United States. Climate Dyn., https://doi.org/ 10.1007/S00382-017-4000-7, in press.

Schulla, J., 2017: Model Description WaSiM. Tech. Rep., ETH Zürich, 347 pp., http://www.wasim.ch/downloads/doku/wasim/ wasim_2017_en.pdf.

Skamarock, W., 2004: Evaluating mesoscale NWP models using kinetic energy spectra. Mon. Wea. Rev., 132, 3019-3032, https:// doi.org/10.1175/MWR2830.1.

Smiatek, G., H. Kunstmann, and J. Werhahn, 2012: Implementation and performance analysis of a high resolution coupled numerical weather and river runoff prediction model system for an Alpine catchment. Environ. Modell. Software, 38, 231-243, https://doi.org/10.1016/j.envsoft.2012.06.001.

,-- , and A. Senatore, 2016: EURO-CORDEX regional climate model analysis for the Greater Alpine Region: Performance and expected future change. J. Geophys. Res., 121, 7710-7728, https://doi.org/10.1002/2015JD024727.

Smith, A., J. Freer, P. Bates, and C. Sampson, 2014: Comparing ensemble projections of flooding against flood estimation by continuous simulation. J. Hydrol., 511, 205-219, https:// doi.org/10.1016/j.jhydrol.2014.01.045.

Teutschbein, C., and J. Seibert, 2012: Bias correction of regional climate model simulations for hydrological climatechange impact studies: Review and evaluation of different methods. J. Hydrol., 456-457, 12-29, https://doi.org/10.1016/ j.jhydrol.2012.05.052.

van den Besselaar, E., M. Haylock, G. van der Schrier, and A. M. G. Klein Tank, 2011: A European daily highresolution observational gridded data set of sea level pressure. J. Geophys. Res., 116, D11110, https://doi.org/10.1029/ 2010JD015468.

Vautard, R., and Coauthors, 2013: The simulation of European heat waves from an ensemble of regional climate models within the EURO-CORDEX project. Climate Dyn., 41, 25552575, https://doi.org/10.1007/s00382-013-1714-z.

Viganò, G., G. Confortola, R. Fornaroli, R. Cabrini, S. Canobbio, V. Mezzanotte, and D. Bocchiola, 2016: Effects of future climate change on a river habitat in an Italian Alpine catchment. J. Hydrol. Eng., 21, https://doi.org/10.1061/(ASCE)HE.19435584.0001293.

Wagner, T., M. Themeß1, A. Schüppel, A. Gobiet, H. Stigler, and S. Birk, 2017: Impacts of climate change on stream flow and hydro power generation in the Alpine region. Environ. Earth Sci., 76, https://doi.org/10.1007/s12665-016-6318-6.

Wagner, A., D. Heinzeller, S. Wagner, T. Rummler, and H. Kunstmann, 2018: Explicit convection and scale-aware cumulus parameterizations: High-resolution simulations over areas of different topography in Germany. Mon. Wea. Rev., 146, 1925-1944, https://doi.org/10.1175/MWR-D-17-0238.1.

Zacharias, S., and Coauthors, 2011: A network of terrestrial environmental observatories in Germany. Vadose Zone J., 10, 955973, https://doi.org/10.2136/vzj2010.0139.

Zubler, E. M., A. M. Fischer, F. Fröb, and M. A. Liniger, 2016: Climate change signals of CMIP5 general circulation models over the Alps - Impact of model selection. Int. J. Climatol., 36, 3088-3104, https://doi.org/10.1002/joc.4538. 